\title{
Assessing the pile base capacity from a Static Load Test on model piles
}

\author{
Michał Baca, Włodzimierz Brząkała and Jarosław Rybak* \\ Wroclaw University of Science and Technology, Faculty of Civil Engineering Wyb. \\ Wyspiańskiego 27, 50-370 Wrocław, Poland
}

\begin{abstract}
A static load test of a pile provides information about the pile bearing capacity. Nevertheless sometimes more precise information can be needed, e.g. what part of load applied to the pile is carried by its base and its shaft. Many kinds of bi-directional static tests offer the possibility of a separate investigation of the behaviour of pile base and shaft. In these tests, however, the shaft works in a different direction than in actual pile working conditions. In this paper, the authors focus on the results of a static load test on model piles, which make it possible to solely investigate the pile base capacity. The paper describes the construction of a test stand and the testing procedure, and presents the first results of the preformed tests.
\end{abstract}

\section{Introduction - Static Load Test of foundation pile}

A Static Load Test (SLT) is popularly considered the most reliable method of a pile testing [1]. In this test, the load is gradually applied to a pile head by means of hydraulic jack and the displacements of the pile head are measured according to applied load. Results of the tests can be presented on a load-displacement chart, which forms the basis for the evaluation of a pile bearing capacity [2]. However, the results that can only be received from the test are the full capacity of the pile and the pile displacement which appears under a particular load. More detailed information can be derived only from the tests additionally instrumented for measuring other specific values.

The idea of evaluating separately the load capacity of a pile base and a pile shaft firstly appeared in Osterberg Test [3]. Recently, the separate evaluation of these two pile parts was proposed in a Slovakian method Vuis-P [4], an Austrian method of evaluation capacity of a micropile Hay Proof System [5], and a Polish method of pipe piston testing [6-8]. More specific information can be useful especially when static load test is used for the designing process. Dividing full capacity of a pile into the capacities of the pile base and the pile shaft can provide data which help us identify the weakest points of the pile and to decide which of its parts should be improved to ensure the stability of the whole pile construction. Some efforts, based on Cone Penetration Test (CPT), were already published in works [9, 10]. Full scale pile base capacity testing by means of standard SLT or bi-directional testing were presented in references $[11,12]$.

\footnotetext{
* Corresponding author: jaroslaw.rybak@pwr.edu.pl
} 


\section{The idea of model testing - test stand description}

For the purpose of performing model pile testing, a designed test stand was prepared. The test stand consists of a wooden container, strengthened by steel frames and transportation belts on its walls to avoid deformation under pressure during the load test (Figure 1). The container was $1.25 \mathrm{~m}$ long, $1.15 \mathrm{~m}$ wide and $1.50 \mathrm{~m}$ high (Figure 2).

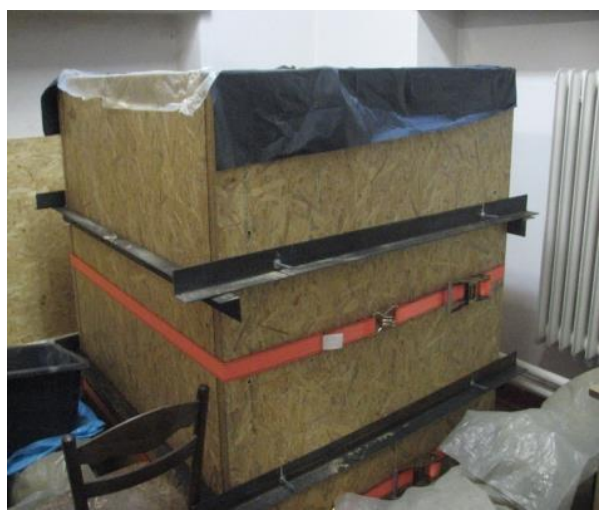

Fig. 1. The test stand for SLT in laboratory scale

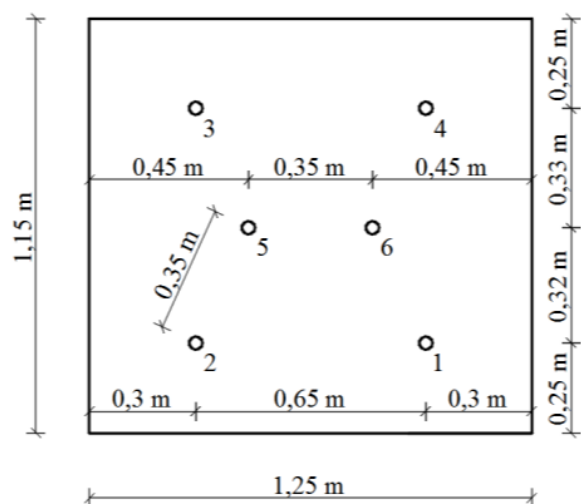

Fig. 2. Dimensions and layout of test pile model

After the container was set, it was gradually filled with medium sand to the level of $1.2 \mathrm{~m}$. The test stand filled with sand is presented in Figure 1. The sand was compacted during its installation and its densification was measured by means of dynamic plate load test (Figure 3 ) and standard (constant volume) cylinder method (Figure 4).

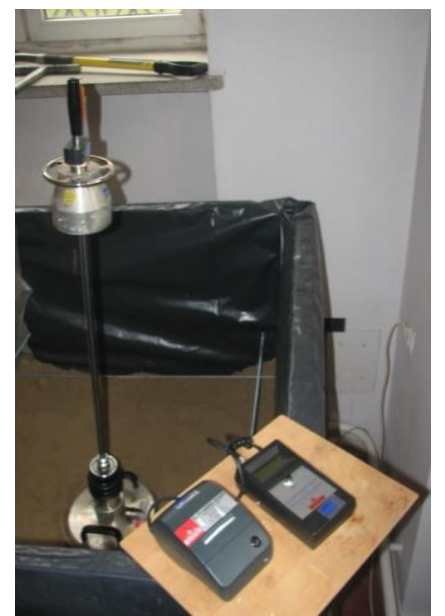

Fig. 3 Dynamic Plate Test of sand compaction

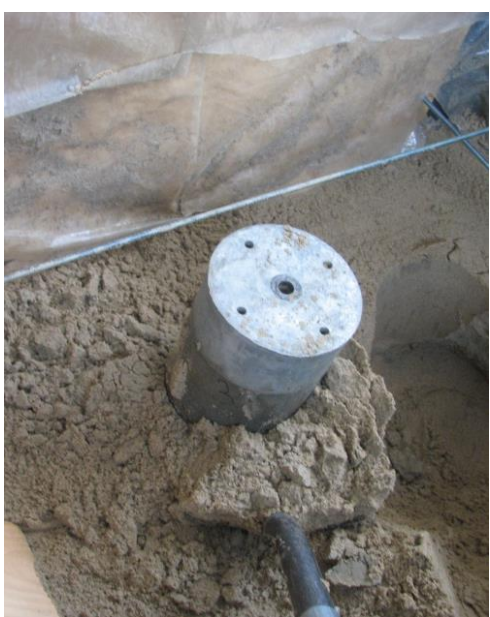

Fig. 4. Standard volume cylinder method

Basic geotechnical parameters of a sand used for model testing were juxtaposed in Table 1.

Table 1. Parameters of a sand used in test

\begin{tabular}{|c|c|}
\hline Type of soil & Medium sand \\
\hline Density & $1,906 \mathrm{~g} / \mathrm{cm}^{3}$ \\
\hline Natural moisture & $7,0 \%$ \\
\hline Uniformity coefficient & 5,2 \\
\hline
\end{tabular}




\section{Tested model pile and its installation}

The pile consist of a $1 \mathrm{~m}$ steel pipe with $40 \mathrm{~mm}$ external diameter (Figure 5), $2 \mathrm{~mm}$ wall thickness and a steel bottom which models the base of a pile (Figure 6). In order to provide load transmission only to the pile base, a perch from dynamic load test was screwed to the base of a pile (Figure 7).

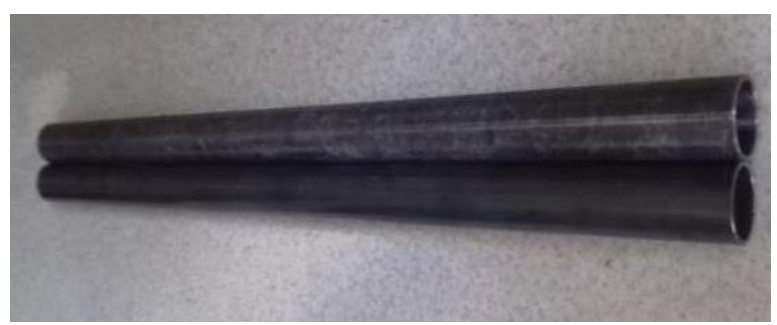

Fig. 5. Steel pipes with $40 \mathrm{~mm}$ external diameter

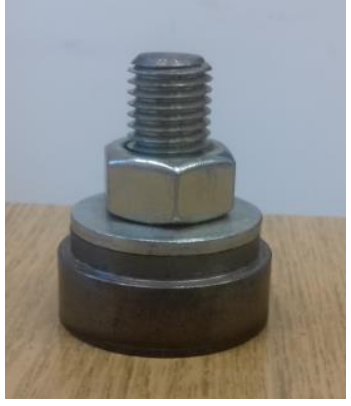

Fig. 6. Steel bottom of pile model.

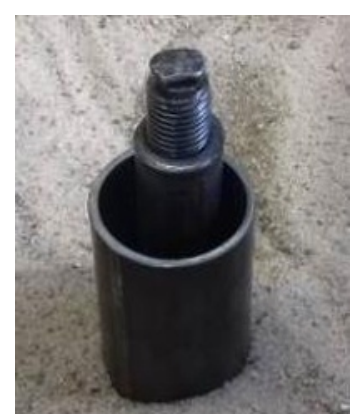

Fig. 7. A perch screwed to pile base

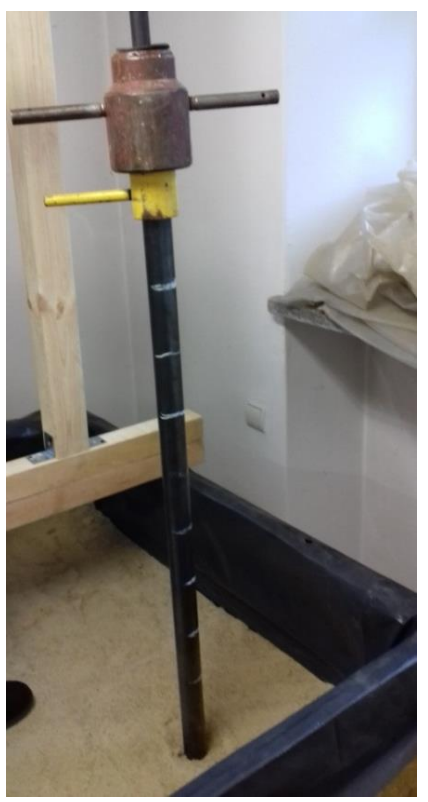

Fig. 8. The model pile driving by means of DPL equipment

After filling the container with a sand the pile models were driven by means of a Dynamic Probe Light (DPL) to the depth of $0.8 \mathrm{~m}$ (Figure 8), which provided the embedment equivalent to 20 times of its diameter value. During the installation the number of standard blows to drive the model pile on each $0.1 \mathrm{~m}$ was monitored and recorded. The graphic representation of standard blows number needed to drive the model pile $\mathrm{nr} 1$ and the model pile $\mathrm{nr} 2$ are presented in Figure 9a and Figure 9b, respectively. It must be underlined, that driving reports presented below confirm the uniform compaction of sand in the container. This uniformity is a crucial factor when test results are expected to form the basis for the calibration of numerical modeling of pile testing [13-15] and reliability analysis [16].

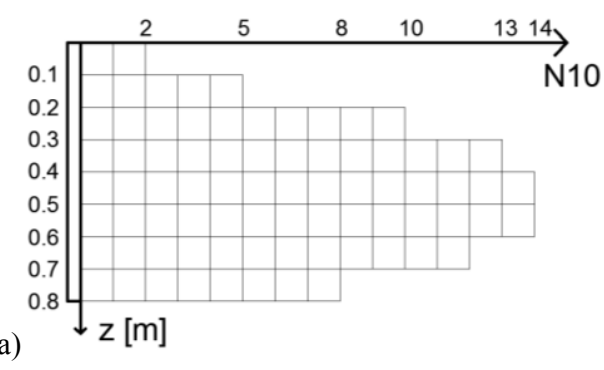

b)

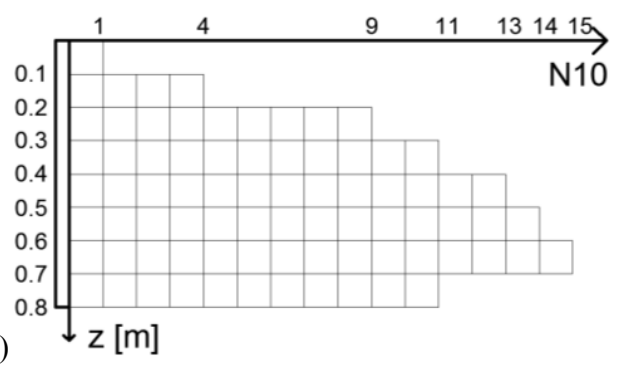

Fig. 9. Results of number of blows for each $0.1 \mathrm{~m}$ of pile embedment

a) pile $\mathrm{nr} 1, \quad$ b) pile $\mathrm{nr} 2$ 
During the test, the load was applied by means of a screw jack only to the pile base through the perch. The value of the applied load was measured by a load cell and the displacement was measured by a displacement sensor. The test stand with reaction frame during the preformed test is presented in Figure 10a. Another mode of pile base testing, using self balanced bi-directional testing appliance (Figure 10b) was also examined with regard to the analysis of pile base capacity under various pile shaft loading. All the results were recorded in a computer memory constantly during the test. All tests were performed to the moment when the pile base bearing capacity was achieved.

a)

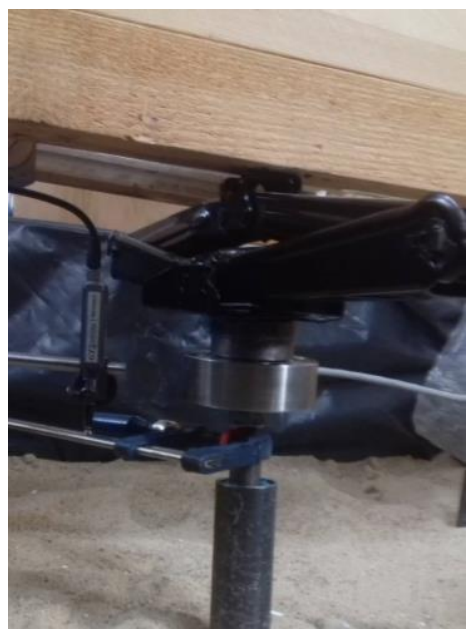

b)

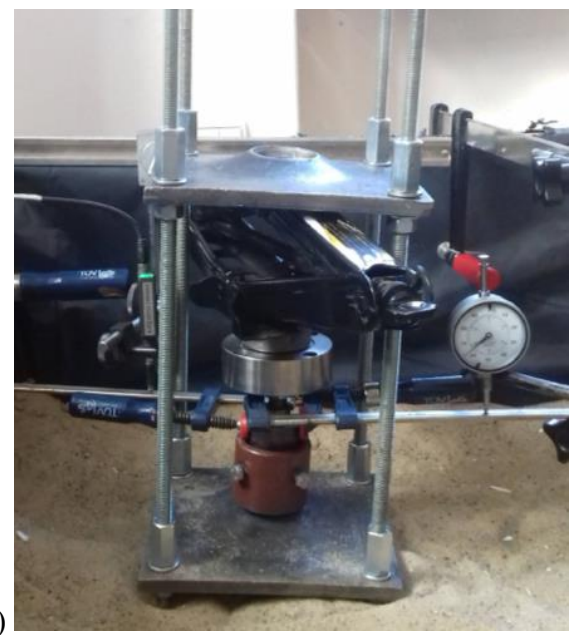

Fig. 10. Static load test of the model pile base a) reaction frame method b) self-balanced appliance

\section{Exemplary results of the tests}

The results of performed tests for two different piles are presented on load-displacement curves for piles 1 and 2 in Fig. 11 and Fig. 12, respectively. The results of the test were approximated by the Brinch-Hansen $80 \%$ method [17] to evaluate the capacity of a pile base.
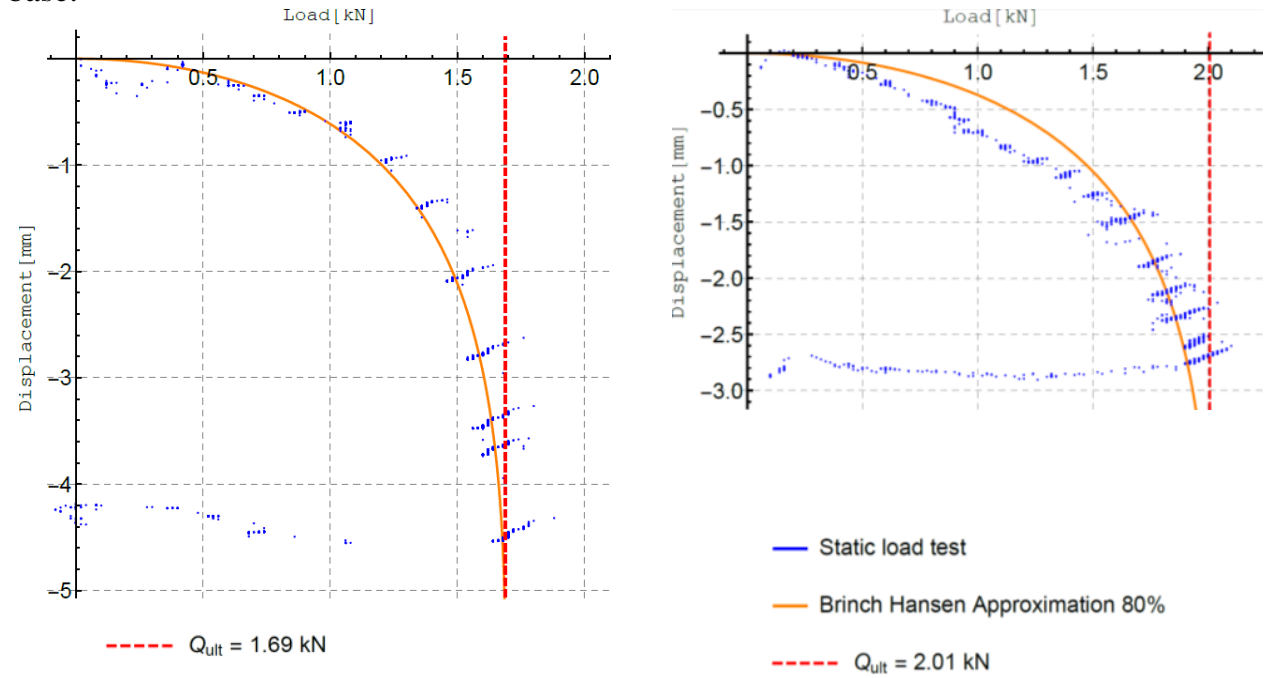

Fig 11. Result of SLT of model pile nr 1.

Fig. 12. Result of SLT of model pile nr 2. 


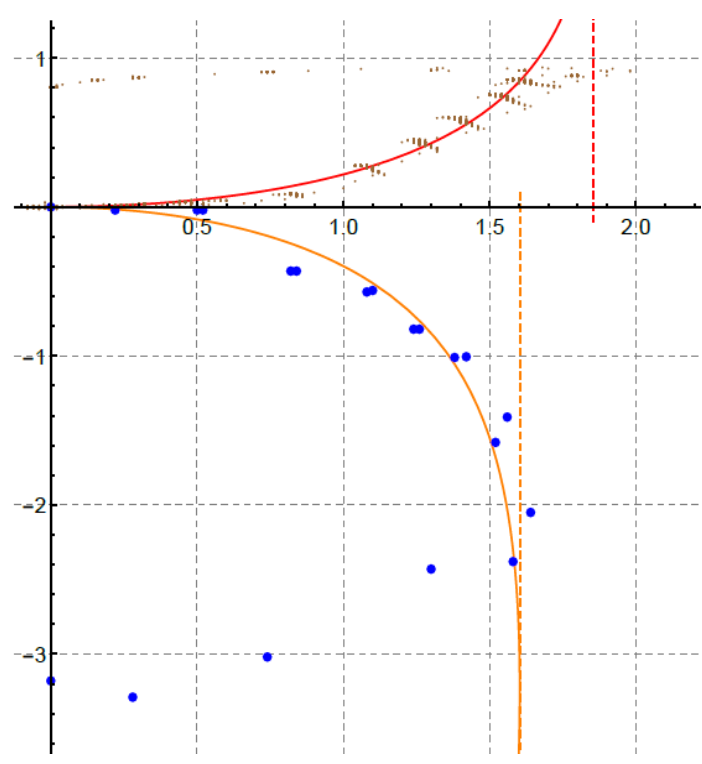

Fig 13. Results of bi-directional test of pile nr 1
Results of a bi-directional test of pile nr 1 is given in Figure 13. It can be found that "lifting" of the pile shaft (external pipe) causes small reduction in evaluated pile base capacity $(1.60 \mathrm{kN}$ for bi-directional test compare to $1.63 \mathrm{kN}$ in the previous case). It is the result of the reduced vertical stress at the level of the pile base.

Description of data on Figure 13

$\begin{array}{ll}- & \text { Pile base settlement under test } \\ - & \text { Pile shaft uplift under test } \\ - & \text { Pile base } 80 \% \text { approximation } \\ - & \text { Pile shaft } 80 \% \text { approximation } \\ ---- & \mathrm{Q}_{\mathrm{b}, \mathrm{ult}}=1.60 \mathrm{kN} \quad \text { (base capacity) } \\ ---- & \mathrm{Q}_{\mathrm{s}, \mathrm{ult}}=1.85 \mathrm{kN} \quad \text { (shaft capacity) }\end{array}$

It must be underlined that both methods of pile base load testing provide valuable data, however the bi-directional test may tend to underestimate the results. It is consistent with engineering intuition that reduced principal stress at the pile base level may result in lower capacity of the tested pile. Bi-directional testing confirms another expected finding: limit state observed as pile base capacity was reached at smaller value of pile base displacement.

\section{Summary and conclusions}

The new method of assessing pile base capacity from the pile static load test was introduced and examined in laboratory condition. The results of the static load tests performed on laboratory scale using two different models of load transmission from the pile base are promising. The connection between number of standard blows during pile driving and the results of the tests can be observed. More strokes for model pile $\mathrm{nr} 2$ results in its greater capacity of a pile base. Furthermore, a greater number of blows indicates more stiff soil which means that the capacity of pile base $\mathrm{nr} 2$ is achieved at a lower value of displacement. The tests confirmed that the method can be applied pile base capacity evaluation. Moreover, similar testing methodology can also be used to perform static load test of a full pile model. Preliminary results, with vertical load applied to a shaft pipe was presented in the authors' previous studies [18]. Therefore, evaluation of a full pile bearing capacity and pile bearing capacity of a pile base can be performed on one test stand for numerous model piles, which can provide more accurate evaluation of pile behaviour in soil. The determining of the pile capacity underestimation range in bi-directional testing and the influence of time [19] on pile base and full pile capacity will be a subject of further analysis. So far, there is no doubt that the presented model testing confirms the initial intuitions.

The authors would like to thank Mota Engil Central Europe for providing soil material for the construction of model pile testing at Wrocław University of Science and Technology. Our deep gratitude is addressed B.U.G. GEOTECH for help in construction and assembling pile models and bidirectional pile testing appliance. 


\section{References}

1. B.H. Fellenius, Test loading of piles. Methods, interpretation, and new proof testing procedure. ASCE, 101, GT9, 855- 869, (1975)

2. B.H. Fellenius, The analysis of results from routine pile loading tests. Ground Engineering, London, 13, No. 6, 19-31, (1980)

3. J.O. Osterberg, The Osterberg load test method for bored and driven piles the first ten years. $7^{\text {th }}$ Int. Conf. and Exhibition on Piling and Deep Foundations, 1.28. Deep Foundations Institute Vienna, Austria, (1998)

4. P. Velič, P. Mišove, Statické zatažovacie skúšky pilót. Inženýrské stavby, 4, (2013)

5. D.M. Hayden, Pile HAY-Proof-System ${ }^{\circledR}$ (Pile HPS) New Test Method for Static Load Tests of Slender Piles.

6. J. Rybak, M. Baca, T. Żyrek, Practical aspects of tubular pile axial capacity testing, $15^{\text {th }}$ Int. Multidisciplinary Scientific GeoConference Surveying Geology and Mining Ecology Management, SGEM 2015, Albena, Bulgaria, 2 (1), 549-554 (2015)

7. M. Baca, Z. Muszyński, J. Rybak, T. Żyrek, Repeated full scale load tests of closedend steel pile. ESaT $20162^{\text {nd }}$ Int. Conf. on Eng. Sciences and Technologies, Tatranské Matliare, Slovakia, $29^{\text {th }}$ June - $1^{\text {st }}$ July, Technical University of Košice, 1-4, (2016)

8. D. Sobala, G. Tkaczynski, Interesting Developments in Testing Methods Applied to Foundation Piles, IOP Conf. Ser.: Mat. Science and Eng., 245, 022074, (2017)

9. I. Bagińska, M. Wyjadłowski, M. Sacha, Study of the results of static CPTu test for capacity calculation of the pile. 17th International Multidisciplinary Scientific GeoConference, SGEM 2017, Albena, Bulgaria, 17 (12), 825-832, (2017)

10. M. Wyjadłowski, I. Bagińska, J. Rainer, Probabilistic assessment of pile capacity based on CPTu probing including random pile foundation depth, MATEC Web Conf., 196, 01058, (2018)

11. M. Baca, J. Rybak, A.G. Tamrazyan, T. Zyrek, Pile foot capacity testing in various cases of pile shaft displacement, Int. Multidisciplinary Scientific GeoConference, SGEM 2016, Albena, Bulgaria, 1, 945-950 (2016)

12. M. Baca, Z. Muszynski, J. Rybak, T. Zyrek, A.G. Tamrazyan, Cyclic load tests of driven pile base capacity, Advances and Trends in Engineering Sciences and Technologies II - Proc. of the 2nd Int. Conf. on Eng. Sciences and Technologies, ESaT 2016, 723-728 (2017)

13. M. Drusa, J. Vlček, Numerical approach to pile load test using 3D finite element method, Komunikácie, 16 (4), 94-97 (2014)

14. M. Baca, W. Brząkała, Numerical simulations of pile static load test, $X X$ Meždunarodnaâ mežvuzovskaâ naučno-praktičeskaâ konferenciâ studentov, magistrov, aspirantov i molodyh učenyh, Moscow, Russia, 1129-1131 (2017)

15. M. Baca, W. Brząkała, Numerical modeling of pile installation influence on surrounding soil, $17^{\text {th }}$ International Multidisciplinary Scientific GeoConference, SGEM 2017, Albena, Bulgaria, 17 (12), 619-626 (2017)

16. J. Bauer, W. Puła, M. Wyjadłowski, Pile load test results as a basis for reliability calculation with parabolic response surface. Technicki Vjesnik, 25 (2), 558-564, (2018)

17. J. Brinch Hansen, Discussion, Hyperbolic Stress-Strain response, Cohesive soil., J. of Soil Mechanics and Foundation Engineering Division, ASCE, 89, 241-242, (1963)

18. M. Baca, J. Rybak, First results of pipe pile static load test in small laboratory scale, MATEC Web Conf., 251, 04038, (2018)

19. Z.G. Ter-Martirosyan, A.Z. Ter-Martirosyan, V.V. Sidorov, Creep and long-term bearing capacity of a long pile in clay $18^{\text {th }}$ Int. Conf. on Soil Mech. and Geotech. Eng.: Challenges and Innovations in Geotechnics, ICSMGE 2013, 4, 2881-2884, (2013) 